\title{
DESAIN SARANA BAWA ALAT PERKEBUNAN
}

\author{
Dita Andansari \\ Staf Pengajar Program Studi Desain Produk, Jurusan Desain \\ Politeknik Negeri Samarinda \\ e-mail: ditaandansari@yahoo.com \\ Suharbianto \\ Staf Pengajar Program Studi Desain Produk, Jurusan Desain \\ Politeknik Negeri Samarinda
}

\begin{abstract}
ABSTRAK
Berkebun merupakan sebuah kegiatan budaya nenek moyang yang sudah turun - temurun dari zaman manusia pertama yang ada di muka bumi ini sampai manusia yang ada pada saat ini. Berkebun tidak hanya dapat dilakukan di lahan yang luas tetapi juga di pekarangan rumah. Banyaknya peralatan kebun seperti sudip tangan, gergaji, sekateur, pencakar tangan, garpu tangan, dan parang. membawa tas khusus untuk mempermudah membawa perlengkapan tersebut karena sebelumnya perlengkapan tersebut hanya diletakkan di dalam tas ransel bersama perlengkapan lainnya, sehingga harus membongkar saat perlengkapan tersebut akan digunakan. kemudian sering kali setiap menggunakan peralatan berkebun namun setelah memakainya kita terkadang lupa menaruh dan tertinggal setelah digunakan hingga tercecer dan berantakan dimana - mana. Oleh karena itu perlu membuat sarana bawa khusus untuk membawa dan merapikan peralatan perkebunan tersebut. Metode perancangan yang dilakukan yaitu melakukan pengumpulan data, analisa data, menentukan konsep desain, membuat desain alternatif, mengembangkan desain alternatif, hingga desain akhir. Untuk itu, dengan adanya Desain Sarana bawa alat perkebunan, pengguna dapat membawa dan menyimpan peralatan berkebun, dengan desain yang lebih ergonomis, dan estetis yang bernuansa modern.
\end{abstract}

Kata kunci: berkebun, tas, bawa, alat.

\begin{abstract}
Gardening is an activity cultural ancestors which has been passed down from generation to generation that is on the face of this earth until humans are present. Gardening can not only be done on vast land but also in the yard of the house. The large number of garden tools such as sputters, chainsaws, sekateur, hand scrapers, hand forks, and machetes. carrying a special bag to make things easier bring the equipment is before the equipment is only placed in a backpack along with other equipment, so it must be unpacked when the equipment will be used. then often every time using gardening tools but after wearing it we sometimes forget to put and left behind after being used to scattered and cluttered everywhere. Therefore it is necessary to create special means to carry and tidy up the plantation equipment. The design method used is collecting data, analyze the data, determine the design concept, create alternative design, developing alternative designs, to final design. To that end, with the "design of plantation tool bag", users can carry and store gardening equipment, with a more ergonomic design, and aesthetically modern.
\end{abstract}

Keywords: gardening, bag, take, tools. 
Dita Andansari, Suharbianto, Desain Sarana Bawa Alat Perkebunan

\section{Pendahuluan}

Berkebun merupakan sebuah kegiatan budaya nenek moyang yang sudah turun - temurun dari zaman manusia pertama yang ada di muka bumi ini sampai manusia yang ada pada saat ini. Berkebun tidak hanya dapat dilakukan di lahan yang luas tetapi juga di pekarangan rumah. Berkebun merupakan salah satu hobi yang positif dan menyenangkan. Bahkan berkebun, yang selama ini dikenal sebagai saat relaksasi bagi orang dewasa belaka dan memiliki fungsi pencegahan pemanasan global, ternyata juga membawa manfaat terhadap kesehatan anak-anak. Aktivitas fisik yang dilakukan selama berkebun membantu anak-anak dalam mengokordinasikan kemampuan gerak mereka melalui aktivitas di alam bebas. Oleh karena itu sering kali setiap menggunakan peralatan berkebun namun setelah memakainya kita terkadang lupa menaruh dan tertinggal setelah digunakan hingga tercecer dan berantakan dimana - mana. Oleh karena itu perlu membuat sarana bawa khusus untuk membawa dan merapikan peralatan perkebunan tersebut.

Sarana bawa alat perkebunan yang ada di pasaran saat ini terdapat beberapa model yang paling umum digunakan yaitu tas ransel biasa yang menggunakan bahan khusus polyster dan alat perkebunan ditempatkan dalam sarana bawa tersebut. Dari pengamatan sebelumnya beberapa masyarakat biasa menggunakan tas ransel polyster biasa karena lebih mudah digunakan namun ada beberapa masalah yaitu tidak terdapatnya sekat pemisah antara alatalat lainnya yang berupa benda tumpul dan benda tajam sehingga dapat membahayakan pengguna tersebut dan dapat merusak tas ransel tersebut karena bukan dari fungsinya. Dari permasalahan yang dijelaskan di atas dengan banyaknya produk sarana bawa alat perkebunan yang bervariasi sehingga membuat designer untuk memperbaiki produk sarana bawa alat perkebunan tersebut menjadi lebih fungsional, lebih menarik dan bisa digunakan dimana saja pada kebunnya yang berbeda beda tempat sehingga akan minat konsumen untuk membelinya.

Berdasarkan latar belakang tersebut, maka diperlukan sebuah desain sarana bawa alat perkebunan yang mempermudah konsumen membawa, menggunakan, merapikan dan merawat alat perkebunan tersebut. Membuat sebuah sarana bawa alat perkebunan yang sesuai dengan kebutuhan konsumen yang dapat membantu aktifitas tersebut.

\section{Metode Perancangan}

Dalam merancang atau mendesain sebuah produk ini agar perancangan lebih terarah, penulis memilih metode perancangan Goel (1995) dengan langkah-langkah sebagai berikut:

\subsection{Preliminary Desain}

Pengumpulan data dari informasi, analisis data berdasarkan konsep desain makro yang meliputi analisis konsep (konsep fungsi, konsep pemakaian,pemakain pasar, dan konsep produk), penyusunan program desain sketsa awal. Bagian di atas terdiri dari: Perumusan Masalah, Tinjauan Pustaka, Analisis Data dan Spesifikasi Desain

\subsection{Design Development}

Pada tahap ini dibuat alternatif gambar komponen serta rancangan secara wire diagram dengan bentuk 3D (tiga dimensi). Dari bagian yang tertera diatas terdiri dari: Alternatif Desain, Pengembangan dan Alternatif Desain.

\subsection{Final Desain dan Prototype}

Dibuat gambar-gambar yaitu gambar presentasi 3D dan gambar teknik (gambar tampak, potongan, gambar detail dan spesifikasi teknik produk). Tahapan selanjutnya adalah pembuatan komponen-komponen dilakukan assembling (exploded) atau perakitan sehingga menjadi produk (prototype). 
Vol. 5, No. 2, April 2018

III. Pembahasan

\subsection{Analisis Pasar}

Analisis pasar dilakukan guna menentukan sasaran pengguna produk yang dirancang. Penentuan target pasar dapat dilakukan berdasarkan pendekatan-pendekatan sebagai berikut:

\section{Segmentasi Geografi}

Desain sarana bawa alat perkebunan, segmentasi geografi yang ditentukan adalah di kota Samarinda, desa Bayur, Samarinda Utara. Hal ini dikarenakan banyaknya warga desa Bayur yang berprofesi sebagai petani di daerah tersebut.

\section{Segmentasi Demografi}

Usia yang ditentukan sebagai sasaran adalah usia 25 - 50 tahun. Produk ini ditujukan kepada jenis kelamin pria dan wanita, karena warga desa bayur yang berprofesi sebagai petani adalah pria. Petani desa bayur di kota Samarinda adalah warga usia dewasa dengan pendidikan terakhir sekolah menegah kejuruan dan belajar secara otodidak tentang pertanian. Pekerjaan petani desa bayur yaitu sebagai petani yang menggarap sebuah lahan pertanian sehingga nanti terdapat kegiatan bagi hasil dengan pemilik lahan. Dan terdapat juga petani yang memiliki lahan sendiri. Kelas sosial petani desa bayur yaitu petani sebagai pemilik lahan dan petani yang tidak memiliki lahan. Sehingga petani yang tidak memiliki lahan akan bekerja sama dengan petani yang memiliki lahan dengan sistem bagi hasil dan sistem upahan. Jadi dengan adanya produk ini akan memungkinkan menaikan kelas sosial petani tersebut.

\section{Segmentasi Psikografi}

Segmentasi pisikografi ditujukan untuk petani desa Bayur di Samarinda. Gaya hidup petani desa Bayur terlihat dari pakaian yang mereka pakai, seperti baju, celana panjang, kaos kaki, sepatu boots, sarung tangan, topi atau caping, pelindung kepala (masker), dan sarana bawa alat perkebunan. Seperti contohnya pakaian dan peralatan perkebunan yang biasa digunakan memiliki ciri khas berwarna coklat untuk memperlihatkan identitas petani tersebut.

\section{Segmentasi Perilaku}

Perilaku petani desa bayur tergolong berani dan pekerja keras karna bertani adalah bagian dari pekerjaan pokok untuk mencari nafkah dan menghidupi keluarganya, berkerja sebagai petani memiliki jiwa yang kuat dan pantang menyerah ini terbukti beberapa petani dapat mengalami cidera namun dengan kebutuhan hidup petani dan keluarganya petani tetap terus bekerja.

\subsection{Analisis Ergonomi}

Dalam merancang produk, kenyamanan pengguna dalam menggunakan atau membawa sarana bawa alat perkebunan ditentukan oleh ukuran-ukuran dimensi tubuh manusia yang menggunakan produk tersebut. Berikut adalah analisis anthropometri pada produk sarana bawa alat perkebunan: Lebar kantong pada tas diambil dari ukuran tebal tangan dan lebar telapak tangan $95 \%$ tile pria dengan ukuran tebal $4,8 \mathrm{~cm}$ dan lebar tas $8,2 \mathrm{~cm}$. Ukuran ini adalah ukuran maksimal. Ukuran produk tas yang dirancang adalah tebal tas $5 \mathrm{~cm}$ dan lebar kantong $10 \mathrm{~cm}$.

Dimensi tubuh yang digunakan adalah tinggi bahu pada posisi duduk. Gender yang digunakan adalah pria $95 \%$ agar dapat mengakomodir ukuran pengguna secara universal. Tinggi bahu pada posisi duduk pria 95\% adalah ukuran tinggi tas maksi$\mathrm{mal}=65,5 \mathrm{~cm}$. Dalam pengertian yang lain, tinggi tas tidak boleh melebihi ukuran tersebut. Pada perancangan ini, tinggi tas yang didesain adalah $60 \mathrm{~cm}$.

Untuk handle tangan dimensi tubuh yang digunakan adalah lebar tangan. Gender yang digunakan adalah pria $95 \%$ agar dapat mengakomodir ukuran pengguna secara universal. Lebar tangan pria $95 \%$ $=$ ukuran lebar celah tas maksimal $=9 \mathrm{~cm}$. 
Dita Andansari, Suharbianto, Desain Sarana Bawa Alat Perkebunan

Dalam pengertian yang lain, lebar handle tas tidak boleh melebihi ukuran tersebut. Pada perancangan ini, lebar handle tas yang didesain adalah $10 \mathrm{~cm}$.

\subsection{Analisis Konfigurasi}

Analisis konfigurasi untuk menentukan peletakkan yang tepat bagi peralatan kebun yang akan dibawa oleh petani menggunakan sarana bawa ini. Adapun komponen yang ada pada produk sarana bawa alat perkebunan adalah: 1) Kantong sarung tangan, 2) Tempat atau penyimpanan gergaji kecil, 3) Kaitan khusus untuk tangga kecil, 4) Kantong untuk menyimpan karung, 5) Tempat atau penyimpanan Sekateur, 6) Tempat atau penyimpanan tali dan plastik sebagai pembungkus okulasi tanaman, 7) Tempat atau penyimpanan alat sudip tangan, 8) Sekat untuk tempat duduk kecil dengan ukuran maksimal $25 \mathrm{~cm}, 9$ ) Tempat atau penyimpanan Pencakar tangan, 10) Tempat atau penyimpanan Garpu tangan dengan sekat khusus karena sedikit tajam, 11) Tempat atau penyimpanan parang, 12) Tempat atau penyimpanan botol air mineral, 13) Tempat atau penyimpanan perlengkapan P3K
Dari beberapa alternatif yang dibuat, setelah dianalisis terpilih alternatif konfigurasi seperti yang ditunjukkan dalam gambar 1. Karena penyusunan kantung yang ringkas dan tersusun susuai dengan kebutuhan alat ketikan akan di gunakan sehingga dapat juga dapat mempermudah pengguna. Pada alternatif konfigurasi dalam gambar 1 ini tali webbing menyesuaikan dari ukuran badan, karena tas yang dipakai adalah seperti bentuk massanger bag, demi kenyamanan pengguna. Terdapat tempat penyimpanan peralatan kebun yang tersusun secara vertikal untuk memaksimalkan tempat dan peralatan tersebut terlihat rapi an tersusun, kemudian tempat untuk tangga kecil alumunium diletakan pada bagian depan dengan cara di ikat dengan webbing tape nylon, untuk dudukan kecil diletakan pada bagian dalam tas menggunakan slot khusus sehingga akan aman jika dalam perjalanan, dengan menggunakan sistem buka tutup maka untuk alat sekateur terletak pada didalam tas pada bagian atas dan sarung tangan terletak pada bagian samping kanan dan sebelah kiri terdapat kantung untuk botol air mineral dan kantong untuk tali dan plastik, untuk kotak P3K dan karung terletak di bagian dalam tas tepat di atas tempat duduk kecil tersebut.

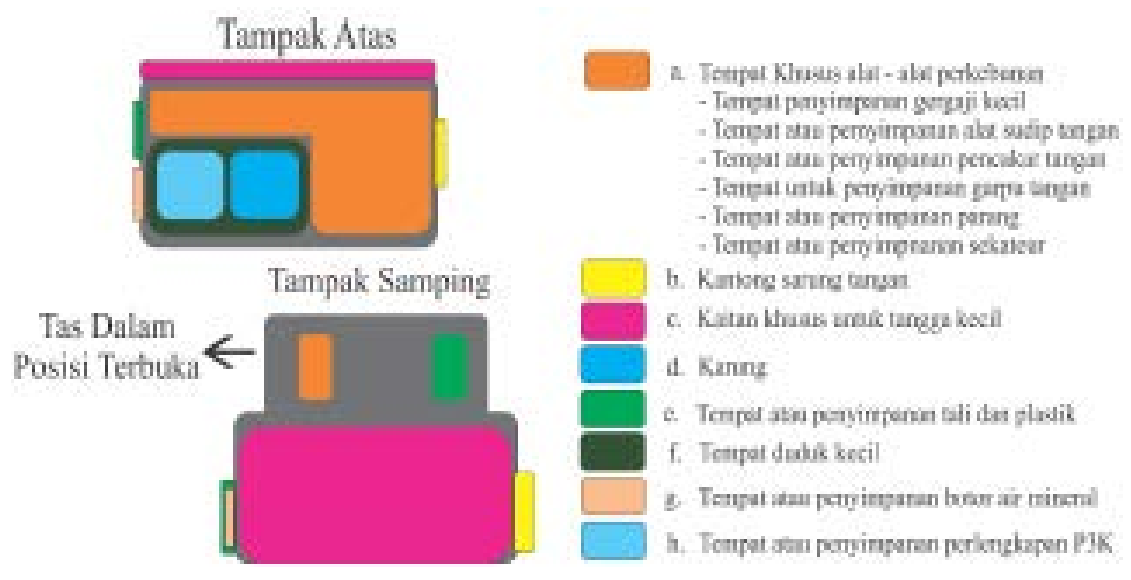

Gambar 1. Alternatif konfigurasi terpilih 
Vol. 5, No. 2, April 2018

\subsection{Analisis Sistem}

Analisis sistem dilakukan untuk menentukan sistem yang sesuai untuk diaplikasikan pada produk sarana bawa alat perkebunan yang akan dibuat. Adapun sistem-sistem yang digunakan pada poduk sarana bawa alat perkebunan sebagai berikut :

\section{Sistem Buka Tutup}

Berdasarkan analisis sistem bukaan jenis resleting (zipper) yang telah dilakukan, zipper yang sesuai untuk diaplikasikan pada produk adalah Coil Zipper. Penggunaan zipper jenis ini disesuaikan dengan aktivitas membuka dan menutup kantong utama pada produk sarana bawa alat perkebunan yang membutuhkan keringkasan. Jenis coil zipper yang digunakan adalah zipper dengan single slider, yaitu zipper atau resleting yang memiliki satu arah bukaan. Jenis zipper ini dipilih sesuai dengan produk yang dirancang sebagai produk yang simple dan ringkas.

\section{Sistem Sambungan}

Berdasarkan analisis sistem sambungan jenis jahitan yang telah dianalisis di atas, sistem sambungan yang sesuai untuk diaplikasikan pada produk ini adalah sitem jahitan kunci, dan jahitan terikat (Bound). Jenis jahitan kunci dipilih untuk diaplikasikan sebagai sistem sambungan pada sarana bawa alat perkebunan karena jenis jahitannya yang kuat saat diaplikasikan pada material yang tebal seperti yang diterapkan pada produk sarana bawa alat perkebunan ini yaitu cordura yang dilapis dengan busa ati, busa Polyfoam kanvas pada bagian dalamnya, selain itu jenis jahitan ini adalah jenis jahitan yang paling umum digunakan. Jenis jahitan Tumpang (Superimposed) pada setiap bagian pola produk. yang terdiri dari 3 lapisan (kulit sintetis pada bagian luar, busa Ati dan busa Polyfoam dibagian tengah dan baby cordura sebagai lapisan dalam), jenis jahitan ini sangat sesuai untuk diaplikasikan pada produk sarana bawa alat perkebunan karena jenis jahitan ini digunakan untuk material 2 lapis atau lebih. Sedangkan pada sisi -sisi tepi produk dan kantong-kantong yang terdapat pada produk, jahitan dibuat terlihat sehingga jenis jahtan yang diaplikasikan adalah jenis jahitan terikat (Bound) sehingga jenis jahitan Bound terlihat rapi.

\section{Sistem Kuncian}

Berdasarkan analisis kelebihan dan kekurangan diatas, sistem kuncian yang paling sesuai untuk diaplikasikan pada produk sarana bawa alat perkebunan adalah sistem kuncian Side Release Buckles, Ladder Lock Buckles dan pengait kuningan bakar. Karena selain kuat, Side Release Buckles dan Ladder Lock Buckles juga tahan lama sehingga sesuai apabila diaplikasikan pada produk sarana bawa alat perkebunan.

\subsection{Analisis Material}

Analisis material dilakukan untuk menentukan material yang sesuai untuk diaplikasikan pada produk sarana bawa alat perkebunan yang akan dibuat. Kebutuhan material produk sarana bawa alat perkebunan harus tebal, kuat, tahan air, tidak mudah robek, dan aman digunakan untuk alat - alat perkebunan, oleh karena itu, menggunakan analisis material 3 bagian lapisan yang akan menghasilkan kualitas yang lebih bagus dan awet jika dibandingkan dengan tas biasa yang hanya memiliki 1 atau 2 bagian lapisan saja. Jenis-jenis pelapis dibagi menjadi 3 bagian yaitu lapisan pertama atau disebut juga lapisan luar, lapisan antara (interlining), dan lapisan dalam (interfacing).

\section{Material Pelapis Pada Lapisan Pertama atau Terluar}

Dalam memilih material yang digunakan untuk lapisan utama pada sarana bawa alat perkebunan, syarat- syarat yang harus dipertimbangkan antara lain adalah material yang digunakan harus tebal, kuat, tidak mudah robek, tahan air (waterproof). Berikut adalah analisis jenis-jenis material 
Dita Andansari, Suharbianto, Desain Sarana Bawa Alat Perkebunan

pelapis pada lapisan utama tas yang dapat diaplikasikan pada produk sarana bawa alat perkebunan:

Berdasarkan analisis yang telah dilakukan, material pelapis pada lapisan utama atau terluar tas yang sesuai untuk diaplikasikan pada sarana bawa alat perkebunan adalah material kain Cordura karena dengan ketahanan kainnya yang lebih tebal dan sangat kuat jika dibandingkan dengan bahan baby ripstop, Cordura memiliki beragam pilihan warna yang kalem dan karakter warnanya. Pilihan warna ini cocok untuk diaplikasikan ke berbagai produk tas. Karakter warnanya juga cocok untuk dipadukan dengan pengguna pria dan wanita segala usia. Selain itu, Cordura juga memiliki harga yang relatif terjangkau, sehingga lebih bersahabat untuk kalangan menengah ke atas, dibandingkan harga bahan baby ripstop yang relatif tinggi. Cordura memiliki spesifikasi yang dapat melindungi perlengkapan yang ada didalamnya dari ancaman cuaca dingin yang ekstrim dapat juga melindungi tas dari benda benda tajam pada alat - alat perkebunan. Secara konstruksi filamen / seratnya, bahan cordura menggunakan bahan dasar benang Nylon (Nilon) yang dikombinasikan dengan kapas, sutra, polyester, dan polypropylene.

Material Pelapis Pada Lapisan Antara (Interlining)

Dalam memilih material yang digunakan untuk lapisan antara (interlining) pada sarana bawa alat perkebunan, syarat-syarat yang harus dipertimbangkan antara lain adalah material yang digunakan harus tebal, kuat dan lebih kokoh dari material pelapis utama dan mampu memperkokoh dan menguatkan bentuk tas.

Berdasarkan analisis yang telah dilakukan, material pelapis pada lapisan antara (interlining) tas yang paling sesuai untuk diaplikasikan pada sarana bawa alat perkebunan adalah material busa ati dan busa Polyfoam. Dengan tekstur padat dan kenyal yang dimiliki oleh busa Ati, material ini sesuai apabila diaplikasikan pada pro- duk sarana bawa alat perkebunan khusus pada bagian kantong yang digunakan untuk membawa atau menyimpan alat - alat perkebunan Sedangkan busa Polyfoam merupakan material pelapis yang sesuai untuk diaplikasikan pada produk sarana bawa alat perkebunan karena busa Polyfoam mampu mempertahankan bentuk dasar produk dan melindungi perlengkapan yang ada di dalamnya. Apabila menggunakan busa Dakron akan membuat tas menjadi lebih tebal dan mengembang sehingga kurang sesuai apabila diaplikasikan untuk produk tas.

Material Pelapis Pada Lapisan Dalam (Interfacing)

Dalam memilih material yang digunakan untuk lapisan paling dalam (interfacing) pada sarana bawa alat perkebunan, syaratsyarat yang harus dipertimbangkan antara lain adalah material yang digunakan harus tebal, kuat tidak mudah lembab dan lebih kokoh dari material pelapis utama dan mampu memperkokoh dan menguatkan bentuk tas.

Berdasarkan analisis yang telah dilakukan, material pelapis pada lapisan ke tiga yaitu lapisan dalam (interfacing) tas yang paling sesuai untuk diaplikasikan pada sarana bawa alat perkebunan adalah material kain Kanvas karena dengan ketebalan sempurna yang dimiliki kain Kanvas akan mampu melindungi pengguna saat membawa atau menyimpan alat - alat perkebunan dan perlengkapan berkebun lainnya pada produk sarana bawa yang akan dibuat jika dibandingkan dengan bahan Laken yang memiliki tekstur bludru sehingga akan susah untuk dibersihkan dan tidak terlalu tebal.

\subsection{Webbing Tape}

Webbing Tape Nylon merupakan tali yang berbentuk pita, terbuat dari bahan nylon. Webbing sering digunakan sebagai tali tambahan pada tas. Webbing Tape nylon digunakan sebagai penutup tepi jahitan pada bagian luar produk sarana bawa alat perkebunan. Selain itu, Webbing Tape tape nylon 
Vol. 5, No. 2, April 2018

memiliki kualitas yang sangat kuat dibandingkan dengan tali webbing tape cotton dan juga webbing tape nylon mudah saat di cuci. webbing nylon juga lebih murah sehingga lebih efisien jika kita mempertimbangkan biaya produksi untuk membuat tas. Salah satu kelebihan lainnya dari tas yang menggunakan webbing nylon adalah lebih awet dari pada webbing cotton. Sehingga tidak masalah jika mengangkat beban yang berat. Berdasarkan analisis yang telah di lakukan, material webbing tape yang akan diaplikasikan untuk produk sarana bawa alat perkebunan adalah webbing tape nylon karena webbing tape nylon mempunyai sifat yang lebih kuat, murah, tahan lama, mudah di cuci dan massa nya lebih ringan dari material webbing tape cotton.

\subsection{Analisis Bentuk}

Analisis bentuk diperlukan dalam menentukan bentuk yang sesuai yang akan diterapkan pada produk. Dalam mendesain sarana bawa alat perekbunan ini, berdasarkan beberapa pendekatan bentuk yang telah dianalisis, pendekatan bentuk dilakukan berdasarkan gaya-gaya desain yang dirasa cocok untuk dipakai.

Berdasarkan pendekatan gaya yang telah dianalisis, gaya desain modern dipilih, karena memiliki bentuk yang lebih geometris dan simple Gaya modern juga memiliki desain yang, bersih, fungsional, stylish dan selalu mengikuti perkembangan jaman yang berkaitan dengan gaya hidup modern yang sedang berkembang pesat. Karena rata - rata karakter pria yang cenderung menyukai bentuk- bentuk yang sederhana dan simpel, selain itu bentuk yang simpel dipilih, karena menyesuaikan dengan aktivitas berkebun yang membutuhkan suatu sarana bawa dengan bentuk yang tidak rumit serta pemakaiannya yang praktis.

\subsection{Analisis Warna}

Analisis warna diperlukan guna menentukan warna yang sesuai untuk diaplikasikan pada produk sarana bawa alat prekebunan. Pendekatan yang digunakan dalam analisis ini adalah hubungan warna dengan psikologi pengguna produk.

Alternative warna yang sesuai setelah dilakukan analisis untuk diterapkan pada produk adalah warna hitam, hijau dan warna coklat. Warna hitam adalah warna yang mudah untuk dikombinasikan dengan warna lain. warna hitam dipersepsi sebagai ketenangan, keheningan dan fokus, selain itu warna hitam juga dipersepsi sebagai kekuatan, warna yang elegan, kuat, gagah dan perkasa, sehingga warna hitam adalah warna yang sesuai untuk diaplikasikan pada produk sarana bawa alat prekebunan yang desainnya dikhususkan untuk gender pria dan wanita. Karena produk ini akan digunakan di area outdoor maka agar tidak terlihat kotor warna dominan pada produk ini adalah warna hitam, dibandingkan dengan warna hijau dan coklat yang akan terlihat cepat kusam dan berdebu jika digunakan di area outdoor. sedangkan warna hijau akan digunakan sebagai warna aksentuasi pada produk sarana bawa alat perkebunan.

Warna hijau memiliki kesan seperti alami, kesegaran, keberuntungan dan kesederhanaan. Warna hijau adalah warna yang menonjolkan sifat natural, dapat memberikan ketenangan, back to nature dan dan erat dengan kultur Indonesia serta religius. Selain itu, warna hijau membawa reaksi otak kepada kondisi cooling down cocok untuk pengguna yang ingin pergi berkebun dengan sebagai alternatif liburan yaitu berkebun. Dengan warna hitam sebagai warna dominan jika dipadukan dengan warna hijau terlihat lebih kontras jika dibanding menggunkan warna coklat sebagai warna aksentuasi.

\subsection{Desain Alternatif}

Pengembangan desain alternatif merupakan awal atau cikal bakal bentuk perancangan produk yang didesain. Dimana alternatif tersebut dibuat sebanyak lima pilihan, lalu ditentukan satu pilihan saja. 
Dita Andansari, Suharbianto, Desain Sarana Bawa Alat Perkebunan

Berdasarkan analisis yang telah dilakukan, maka alternatif desain yang terpilih adalah alternatif desain dalam gambar 2. Karena tas ini sangat cocok untuk menyimpan peralatan kebun seperti sudip tangan, pencakar tangan, lingga, dan pencabut rumput. Kemudian terlihat lebih kokoh pada bagian slot untuk mengantung tangga dan memiliki bentuk yang organis. Selain itu, tas ini juga memiliki opsi tali tas (jinjing dan selempang) dalam pemakaiannya. Tali selempang digunakan untuk mengantisipasi jika pengguna menggunakan lebih dari satu tas. Dan dapat tambahan tali tas untuk menjinjing agar berat tas tersebut dapat di setarakan oleh tangan pengguna. pada alternative dalam gambar 2 ini memiliki bentuk yang lebih organis. Dengan handle 2 tambahan yang dilengkapi sponse yang membuat pengguna nyaman dan aman sehingga akan memudahkan pengguna untuk membawa sarana bawa terebut. Kemudian untuk proses produksi akan juga lebih mudah dibanding alternative. Desain juga terlihat modern dengan perpaduan komposisi warna serta aksen-aksen kecil yang terdapat pada jahitannya.

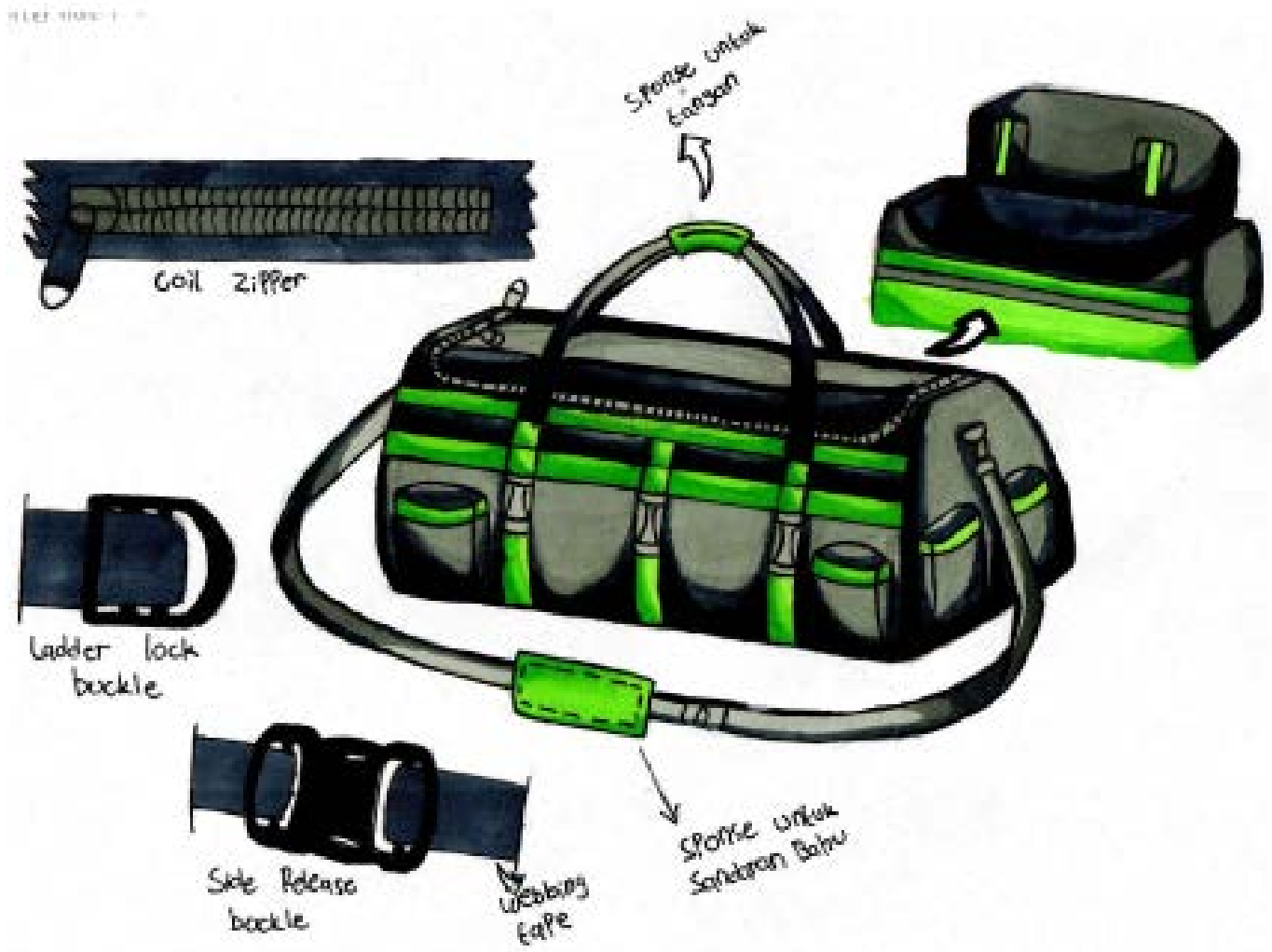

Gambar 2 Desain alternatif terpilih 


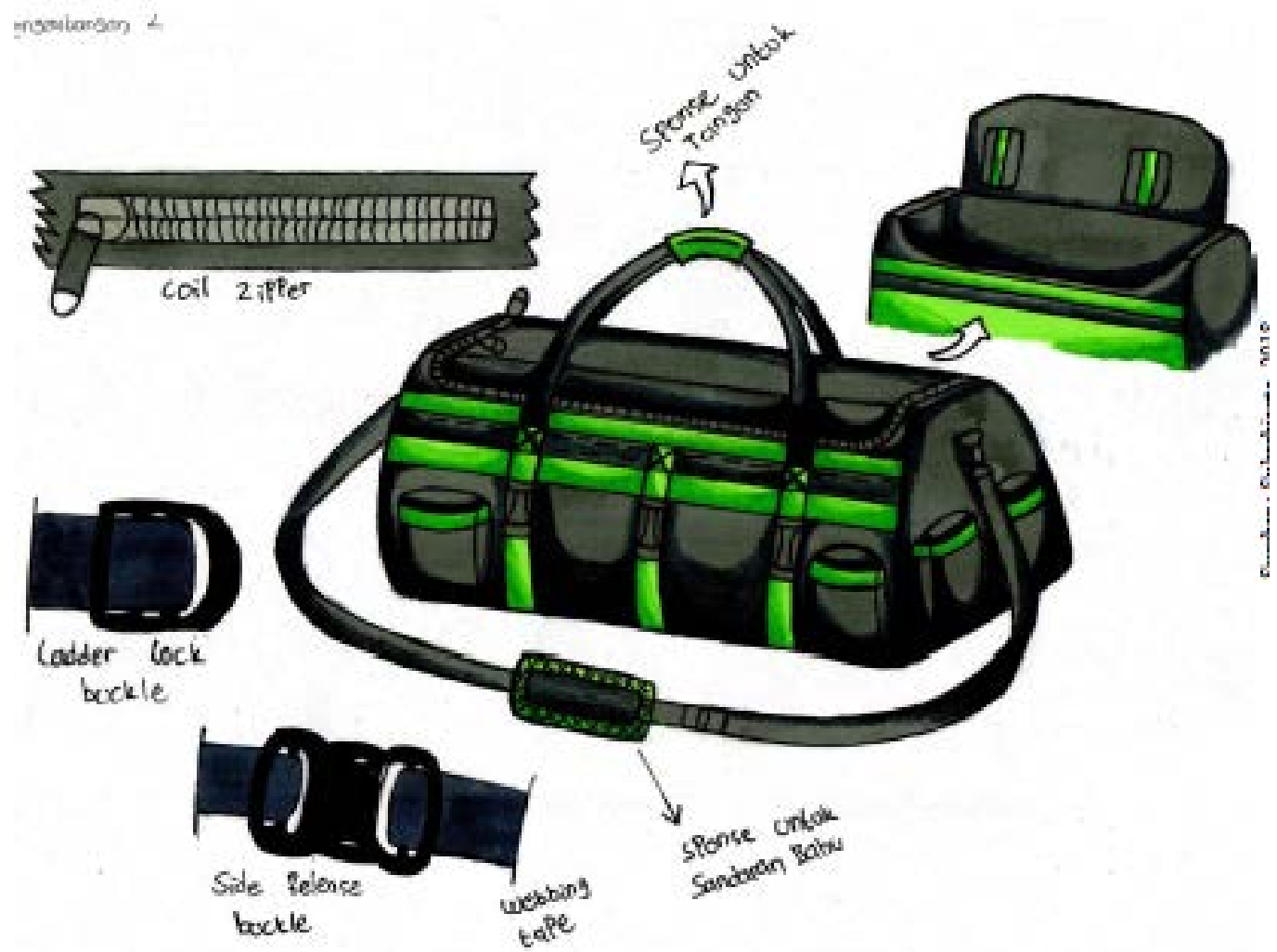

Gambar 3. Desain Pengembangan terpilih

\subsection{Pengembangan Desain Alternatif Terpilih}

Pengembangan desain alternatif terpilih merupakan penyempurnaan bentuk desain alternatif yang telah terpilih sebelumnya. Dimana pengembangan tersebut dibuat beberapa pilihan, lalu ditentukan satu pilihan saja.

Dari analisis pengembangan desain alternatif terpilih, maka yang terpilih adalah pengembangan desain alternatif terpilih yang ditunjukkan dalam gambar 3. Karena selain jahitan yang lebih kuat terdapat perbedaan seperti pengait kuningan bakar yang akan memperkuat dalam ketahanan tas tersebut, sistem buka tutup ini juga cukup mudah dalam pembuatannya.

Pada pengembangan ini menggunakan system jahitan tumpang karena Menciptakan jahitan penahan beban yang rapi dan mudah diaplikasikan pada produk. Namun membutuhkan jasa tukang atau pengerajin yang ahli dan membutuhkan waktu lebih lama di banding pengembangan alternative yang lain.

\subsection{Desain Akhir}

Desain akhir adalah gambaran terakhir produk yang telah tercapai. Dimana desain akhir tersebut terbagi dalam beberapa gambar detail, antara lain adalah gambar presentasi, gambar teknik, dan foto prototipe. Berikut adalah desain akhir produk Sarana Bawa Alat Perkebunan. 


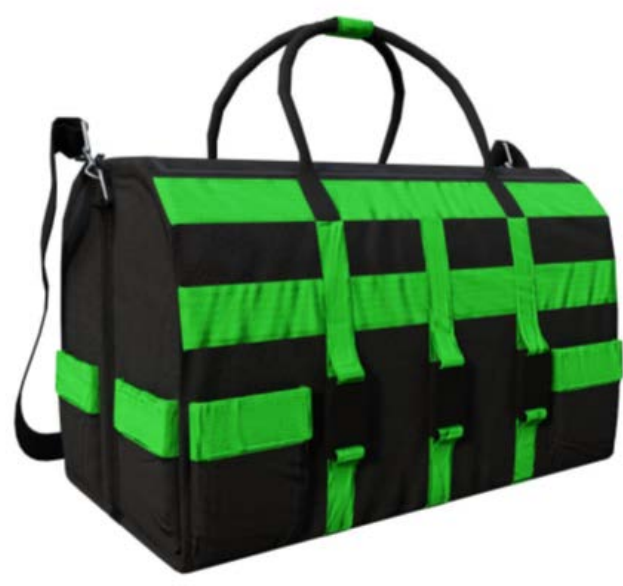

Gambar 4. Gambar Presentasi

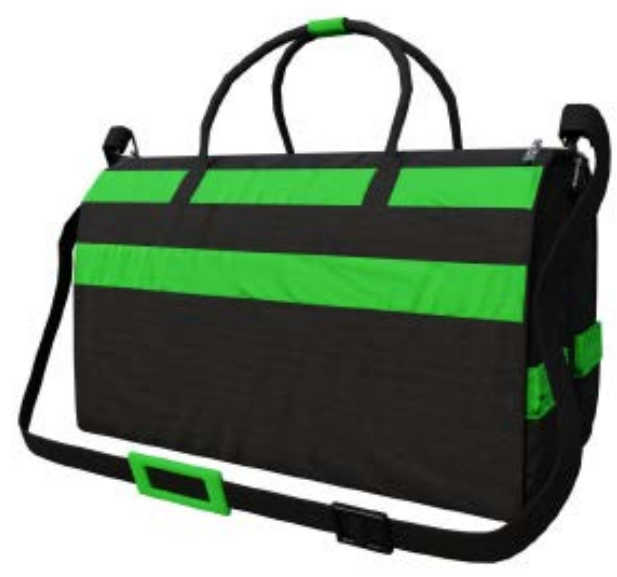

Gambar 5. Gambar Presentasi

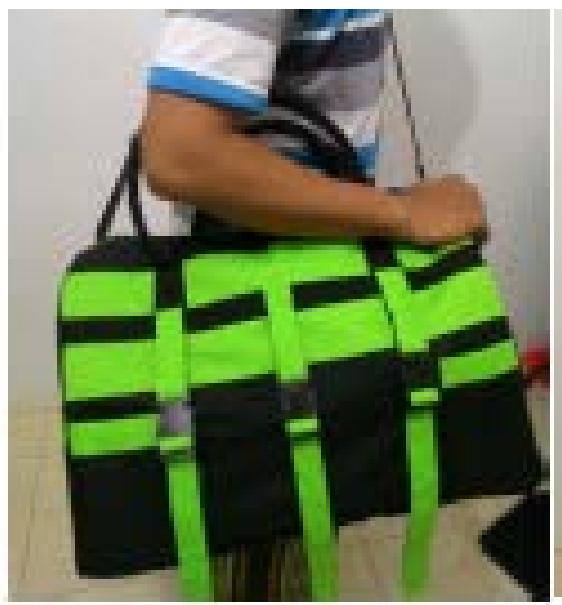

Gambar 6. Prototype produk

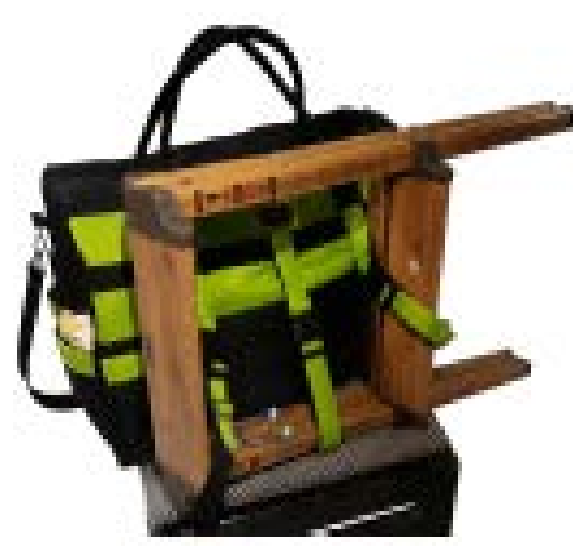

Gambar 7. Prototype produk

\section{Kesimpulan}

Berdasarkan hasil dari perancangan, maka dapat ditarik kesimpulan :

Sarana bawa yang dihasilkan dapat mengakomodir perlengkapan berkebun, karena sarana bawa yang dihasilkan dilengkapi dengan kantong dan sekat-sekat khusus untuk membawa dan menyimpan alat - alat perkebunan.

Sarana bawa yang dihasilkan dirancang dengan bentuk yang modern serta sistem bukaan, sambungan dan kuncian yang tidak rumit, selain itu juga menggunakan material yang kuat dan tebal.

Ke depannya diharapkan ada yang bisa memberi nilai tambah, dengan bentuk yang lebih menarik, agar dapat menjadi produk yang lebih diminati oleh konsumen. Penelitian mengenai aktivitas konsumen yang berkaitan dengan produk yang diracang juga dapat memberikan nilai tambah produk tersebut karena kebutuhan konsumen telah terpenuhi. Untuk mendapatkan hasil yang maksimal perlu adanya pengembangan lebih lanjut mengenai dimensi yang telah di buat dan penambahan fungsi yang dapat dimasukan kedalam produk, sehingga produk akan menjadi lebih baik 
Vol. 5, No. 2, April 2018

\section{DAFTAR RUJUKAN}

Ahmad, Dra Sulasmi Darprawira W. (2002). Teori Warna dan Kreatifitas Penggunanya. Bandung: ITB

Cahyadi, Dwi. (2014). Aplikasi Mannequin Pro Untuk Desain Industri. Yogyakarta: LeutikaPrio.;

Kasali, Reynald. (1998). Membidik Pasar Indonesia Segmentasi, Targeting dan Positioning. Jakarta: PT Gramedia Pustaka Utama

Nurmianto, Eko. (1996). Ergonomi, Konsep Dasar dan Aplikasinya. Surabaya: PT. Guna Widya.

Retno Asih, Endah. (2017). DESAIN SARANA BAWA PERLENGKAPAN PISAU UNTUK DISCOVERER. Laporan Tugas Akhir pada Jurusan Desain Program Studi Desain Produk Politeknik Negeri Samarinda

Tim Penebar Swadaya. (2008). Agribisnis Tanaman Perkebunan. Jakarta: Organisasi Penebar Swadaya

Zaeniah, Suci. (2015). Perancangan Sarana Penyimpanan Peralatan Membatik. Laporan Tugas Akhir pada Jurusan Desain Program Studi Desain Produk Politeknik Negeri Samarinda.

\section{WEBTOGRAFI}

http://www.annjana.com/2015/06/macam-bahan-pelapis-tas.html https://aris83.wordpress.com/2015/12/13/warna-dalam-multimedia https://fitinline.com/article/read/jenis-kancing/ https://fitinline.com/article/read/7-jenis-resleting-berdasarkan-bahan-baku pembuatannya/ https://fitinline.com/article/read/kain-spunbond/ https://fitinline.com/article/read/jenis-jenis-kain-parasut/

https://fitinline.com/article/read/9-jenis-bahan-yang-dapat-digunakan-se bagai-pelapis-tas/ https://fitinline.com/article/read/mengenal-webbing-tas/

https://fitinline.com/article/read/vintage-style

http://konveksitasonline.com/bahan-yang-sering-digunakan-membuat-tas

http://www.ilmugrafis.com/pengertian-arti-warna

http://mangkoko.com/ruang_baca/psikologi-warna-biarkan-warna-berbicara: 23 Desember 2016).

Nurmianto. (1996). Variable Antropometri. Diakses Januari 10, 2018 http://ergonomi-fit. blogspot.co.id

http://www.menarazipper.com/selangpiping-79541 